Original paper

\title{
Complex magmatic and subsolidus compositional trends of columbite-tantalite in the beryl-columbite Šejby granitic pegmatite, Czech Republic: role of crystal-structural constraints and associated minerals
}

\author{
Milan NOVÁK' ${ }^{1}$ Štěpán CHLÁDEK²*, Pavel UHER², Petr GADAS ${ }^{1}$ \\ ${ }^{1}$ Department of Geological Sciences, Masaryk University, Kotlářská 2, 61137 Brno, Czech Republic \\ ${ }^{2}$ Department of Mineralogy and Petrology, Comenius University, Ilkovičova 6, 84215 Bratislava, Slovakia; st.chladek@seznam.cz \\ * Corresponding author
}

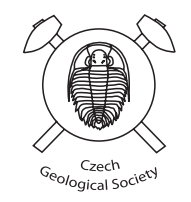

\begin{abstract}
The simply zoned Šejby pegmatite of beryl-columbite subtype is enclosed in migmatitized gneisses - country rocks of the southern part of the Central Moldanubian Plutonic Complex, Bohemian Massif, Czech Republic. The columbite-group minerals (CGM) occur mostly in blocky K-feldspar unit. Primary magmatic CGM [columbite-(Fe)-tantalite-(Fe)], show an interesting compositional and textural evolution. Subhomogeneous cores of columbite-( $\mathrm{Fe})-$ tantalite-( $\mathrm{Fe})(\mathrm{A})$ are surrounded by heterogeneous intermediate zones (B) and (C) with irregular to oscillatory zoning and mutually comparable compositions. Zone (B) contains grains of tapiolite- $(\mathrm{Fe})$ and inclusions of pyrite decomposed into a mixture of secondary jarosite-group minerals. In the next zone (C), irregular Mn-enriched patches occur and in the outermost thin zone (D) CGM exhibit fine oscillatory zoning typically developed at crystal terminations. The late, subsolidus CGM include patchy-zoned Mn-enriched columbite-(Fe) and late columbite-( $\mathrm{Fe}$ ) veinlets both formed at the expense of their magmatic precursors in the zone C; the veinlets are also present in the zone D. Similar but fine patches and veinlets are developed around jarosite pseudomorphs after pyrite. The compositional evolution of CGM shows a slight increase in $\mathrm{Ta} /$ $\mathrm{Nb}$ and $\mathrm{Mn} / \mathrm{Fe}$ in the zones $\mathrm{A}$ and $\mathrm{B}$ followed by a reverse trend to elevated $\mathrm{Nb}$ and $\mathrm{Fe}$ in the zone $\mathrm{C}$ and, in particular, in the zone D. Complex subsolidus fluid-melt interactions that generated patches and veinlets caused only minor changes in $\mathrm{Ta} / \mathrm{Nb}$ and slight Mn-enrichment. Tantalum depletion in veins close to jarosite pseudomorphs after pyrite indicates higher mobility of Ta in acidic low-temperature fluids.
\end{abstract}

Keywords: columbite-group minerals, tapiolite, compositional trends, $\mathrm{Nb}-\mathrm{Ta}$ and $\mathrm{Fe}-\mathrm{Mn}$ fractionation, granitic pegmatite Received: 22 February, 2018; accepted: 27 August, 2018; handling editor: J. Sejkora

\section{Introduction}

Columbite-group minerals (CGM) belong to the most widespread niobium and tantalum phases in geochemically highly evolved rocks, in particular leucogranites and granitic pegmatites. As mafic minerals, they represent also essential carriers of $\mathrm{Fe}$ and $\mathrm{Mn}$, and in specific cases also $\mathrm{Mg}$ and $\mathrm{Ti}$ in the host rocks of distinctly leucocratic character.

Compositional variations of CGM, especially $\mathrm{Nb}-\mathrm{Ta}$ and $\mathrm{Fe}-\mathrm{Mn}$ pairs, are sensitive indicators of magmatic to subsolidus evolution of the parental rock. During primary magmatic crystallization, they commonly show a progressive increase in one or both of the $\mathrm{Ta} /(\mathrm{Ta}+\mathrm{Nb})$ and $\mathrm{Mn} /(\mathrm{Mn}+\mathrm{Fe})$ ratios, as illustrated by distinct evolutionary trends in the columbite quadrilateral diagram (e.g., Černý and Ercit 1985, 1989; Černý et al. 1986; Lahti 1987, 2000; Spilde and Shearer 1992; Mulja et al. 1996; Tindle and Breaks 2000; Galliski and Černý 2006; Beurlen et al. 2008; Badanina et al. 2015; Melcher et al. 2015). Based on numerous empirical observations of mineral assemblages in the host granites or pegmatites, these trends commonly show a positive relationship to the activity of $\mathrm{F}$ in a parent medium, manifested by the abundance of lepidolite and other F-rich minerals (e.g. Černý 1992; Novák et al. 2003).

Results of experimental works signify the activity of volatiles, chiefly $\mathrm{F}$ and $\mathrm{P}$, in melt (Linnen and Cuney 2005; Aseri et al. 2015). Solubility of individual CGM in melt (Linnen and Keppler 1997; Bartels et al. 2010) and activity of $\mathrm{Li}$ (Linnen 1998; Chevychelov et al. 2010; Bartels et al. 2011; Chevychelov 2014) were used to explain these compositional trends. However, an influence of associated Fe, Mn-bearing minerals such as micas, garnets, primary $\mathrm{Fe}, \mathrm{Mn}$-phosphates or tourmalines was discussed only exceptionally (e.g. Mulja et al. 1996; Van Lichtervelde et al. 2006, 2007; Stepanov et al. 2014). Behaviour of the relevant elements ( $\mathrm{Nb}-\mathrm{Ta}, \mathrm{Fe}-\mathrm{Mn})$ is thus not satisfactorily resolved. Because the $\mathrm{Ta} / \mathrm{Nb}$ ratio is an important indicator of fractionation degree in parental magmatic rocks (Černý et al. 1985; Raimbault 1998; Barth et al. 2000; Černý and Ercit 2005; Melcher et al. 
2015), a study of behaviour of both $\mathrm{Nb}$ and $\mathrm{Ta}$ in distinct geological environments, at variable $\mathrm{P}-\mathrm{T}-\mathrm{X}$ conditions and in various mineral assemblages is long overdue.

Simply zoned beryl-columbite pegmatite from Šejby near Nové Hrady, southern Bohemia, Czech Republic is a unique example of highly leucocratic, $\mathrm{Li}, \mathrm{F}, \mathrm{B}$-poor but $\mathrm{P}$ - and $\mathrm{Nb}, \mathrm{Ta}$-moderately rich system. The almost complete absence of Fe, Mn-bearing silicate or phosphate minerals makes the assemblage CGM + ferrotapiolite + pyrite (completely replaced by secondary jarosite-group minerals) an excellent case study of $\mathrm{Nb}-\mathrm{Ta}$ and $\mathrm{Fe}-\mathrm{Mn}$ fractionation trends from primary magmatic, through early subsolidus to late-veining stages not influenced by associated $\mathrm{Fe}, \mathrm{Mn}$-bearing minerals. Our contribution is focused on a detailed study of textural zoning, compositional variations and trends of columbite-group minerals and tapiolite-(Fe) as tools for understanding the complex magmatic to subsolidus evolution on the example of the Šejby beryl-columbite-subtype pegmatite.

\section{Regional geology and pegmatite characterization}

Leucogranites, marginal pegmatites (stockscheider) and pegmatite dikes are common in the southern part of the Central Moldanubian Plutonic Complex, particularly at the Homolka, Nakolice and Šejby occurrences (Breiter 1998; Heřmánek et al. 1998). In this region, the Central Moldanubian Plutonic Complex is built by the Weinsberg biotite granite (331-323 Ma; Gerdes 2001; Gerdes et al. 2003), Eisgarn two-mica granites (328-326 Ma; Klötzli 1999; Gerdes 2001; Gerdes et al. 2003; Žák et al. 2011)

Tab. 1. Analytical conditions for the EPMA measurement of $\mathrm{Nb}-\mathrm{Ta}$ minerals

\begin{tabular}{lccc}
\hline Element & Line & Calibrant & Detection limits* \\
\hline $\mathrm{W}$ & $L_{\alpha}$ & $\mathrm{W}$ & $2490-2639$ \\
$\mathrm{Nb}$ & $L_{\alpha}$ & columbite "Ivigtut" & $1337-1530$ \\
$\mathrm{Ta}$ & $M_{\alpha}$ & $\mathrm{CrTa}_{2} \mathrm{O}_{6}$ & $842-880$ \\
$\mathrm{Ti}$ & $K_{\alpha}$ & $\mathrm{TiO}_{2}$ & $465-493$ \\
$\mathrm{Zr}$ & $L_{\alpha}$ & ircon & $666-711$ \\
$\mathrm{Sn}$ & $L_{\alpha}$ & $\mathrm{Sn}$ & $1021-1089$ \\
$\mathrm{U}$ & $M_{\beta}$ & $\mathrm{U}$ & $1123-1154$ \\
$\mathrm{Sc}$ & $K_{\alpha}$ & $\mathrm{ScVO}_{4}$ & $341-384$ \\
$\mathrm{Y}$ & $\mathrm{L}$ & $\mathrm{YPO}_{4}$ & $745-806$ \\
$\mathrm{As}$ & $L_{\alpha}$ & 1 ammerite & $608-673$ \\
$\mathrm{Sb}$ & $L_{\beta}$ & $\mathrm{Sb}$ & $1852-1906$ \\
$\mathrm{Bi}$ & $M_{\beta}$ & $\mathrm{Bi}$ & $1235-1403$ \\
$\mathrm{Fe}$ & $K_{\alpha}$ & hematite & $541-574$ \\
$\mathrm{Mn}$ & $K_{\alpha}$ & $\mathrm{Mn}_{2} \mathrm{SiO}_{4}$ & $467-501$ \\
$\mathrm{Mg}$ & $K_{\alpha}$ & $\mathrm{MgAl}_{2} \mathrm{O}_{4}$ & $192-202$ \\
$\mathrm{Ca}$ & $K_{\beta}$ & titanite & $205-213$ \\
$\mathrm{~Pb}$ & $M_{\beta}$ & vanadinite & $882-943$ \\
\hline
\end{tabular}

* Detection limits $(3 \sigma)$ are in ppm and leucogranites $(319 \pm 2 \mathrm{Ma}$; Breiter and Scharbert 1998).

At Šejby, N-S trending dikes of albite-muscovite pegmatitic granite with accessory biotite, topaz, garnet, fluorapatite and columbite-tantalite cut the Weinsberg granite and the surrounding migmatized paragneisses (Matějka and Klečka 1994; Breiter and Scharbert 1998). The exposed pegmatites form zoned N- to S-trending dikes, up to $3 \mathrm{~m}$ thick and $\sim 50 \mathrm{~m}$ long, cutting migmatitized paragneiss close to the granite exocontact (Welser and Zikeš 2013). Going inwards, it consists of a thin border granitic zone $(\mathrm{Kfs}+\mathrm{Ab}+\mathrm{Qz}+\mathrm{Bt})$, a graphic zone (Kfs $+\mathrm{Qz})$, a blocky K-feldspar zone, an albite unit, a coarse-grained muscovite-rich unit and a quartz core (Pavlíček et al. 2009; Welser and Zikeš 2013). At the contact of the blocky K-feldspar zone with the quartz core occur columnar crystals of beryl, up to $15 \mathrm{~cm}$ long, associated with albite, coarse-flaked muscovite and accessory zircon, fluorapatite and $\mathrm{Nb}-\mathrm{Ta}$ oxide minerals. Single euhedral columnar to tabular crystals and aggregates of CGM, up to $15 \mathrm{~mm}$ in size, were found in the blocky K-feldspar zone, muscovite-rich portions and are closely associated with beryl. Hafnium-rich zircon ( 5 to 10 wt. $\% \mathrm{HfO}_{2}$ ) contains tiny inclusions of uraninite (Pavlíček et al. 2009). Moreover, primary Be-phosphates [hurlbutite, (hydroxyl)herderite] along with rare secondary crandallite-group minerals and strengite have been identified (Welser and Zikeš 2013). However, magmatic $\mathrm{Fe}, \mathrm{Mn}$-bearing minerals typical of granitic pegmatites, such as garnet, tourmaline or triplite, have not been described in this pegmatite, except accessory Mn-rich fluorapatite (Pavlíček et al. 2009) and very rare biotite in the outermost granitic zone (Welser and Zikeš 2013).

Cassiterite, CGM, and other associated $\mathrm{Ta}, \mathrm{Nb}, \mathrm{Ti}-$ oxide minerals were found in fine-grained leucogranites and in coarse-grained pegmatites as well as in placers of this region (Breiter 1998). Chemical compositions of CGM, rare ferrotapiolite and ilmenite from leucogranites, granitic pegmatites and placers were studied by several authors (Novák et al. 1994; Frýda and Breiter 1995; Uher 1998; Pavlíček et al. 2009; Welser and Zikeš 2013). All these minerals show similar compositional characteristics: significant $\mathrm{Nb} / \mathrm{Ta}$ fractionation but rather constant and mostly low $\mathrm{Fe} / \mathrm{Mn}$ ratio.

\section{Methods}

The Cameca SX-100 electron microprobe at the Laboratory of Electron Microscopy and Microanalysis, the joint facility of the Masaryk University and Czech Geological Survey in Brno, was used to determine the chemical composition of minerals. The wavelength-dispersion mode and the following analytical conditions were applied: an 

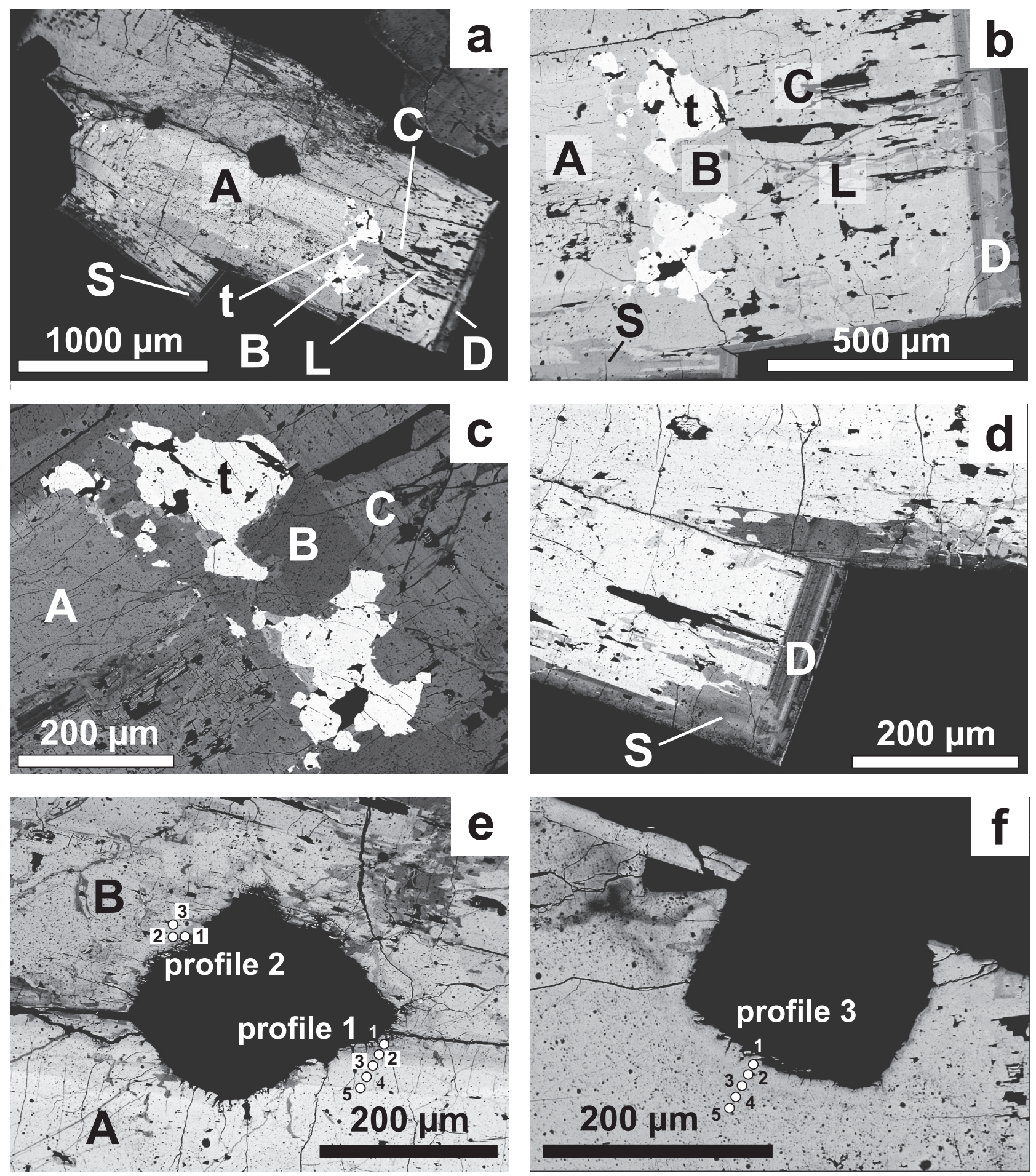

Fig. 1 Back-scattered electron (BSE) images of Nb-Ta minerals from the Šejby pegmatite. a - Columbite-(Fe) to tantalite-(Fe) showing distinct textural variations: central zone (A), irregular intermediate zone B with anhedral bright ferrotapiolite grains, oscillatory-zoned intermediate zone C and thin outer zone (D) showing oscillatory zoning. These primary zones are distinctly replaced by subsolidus patches (S) and late veinlets (L). Dark inclusions are pyrite replaced by a mixture of secondary jarosite-group minerals. The following figures are details of the Fig. 1a: $\mathbf{b}-$ The intermediate zone B with anhedral bright inclusions of tapiolite-(Fe) and other primary zones, note the significant replacement of border zones by subsolidus patchy portions (S) and late veining (L); c - Central zone (A) and adjacent irregular textures of intermediate zone B with anhedral bright inclusions of ferrotapiolite. Adjacent oscillatory-zoned intermediate zone C contains pyrite decomposed into mixture of secondary jarosite-group minerals (dark inclusions); $\mathbf{d}$ - Thin outer zone (D); note that primary oscillatory zoning in crystal rim succumbed to alteration of subsolidus patchy portions (S); e - Dark inclusion of pyrite totally decomposed into a mixture of secondary jarosite-group minerals, situated at the contact of the central (A) with the intermediate zone B, including profiles 1 and $2 ; \mathbf{f}$-Crystal rim with marked position of the profile 3 and a dark inclusion of decomposed pyrite. 
acceleration voltage of $15 \mathrm{kV}$, a beam current of $20 \mathrm{nA}$, and a beam diameter of $2 \mu \mathrm{m}$. The data were reduced using the PAP routine of Pouchou and Pichoir (1985). The remaining analytical details are given in Tab. 1.

\section{Results}

\subsection{Textural relations and internal zoning of Nb, Ta-oxide minerals}

The examined CGM were found on a loose fragment of massive quartz in contact with blocky K-feldspar close to outcrops of pegmatite dikes (see Welser and Zikeš 2013). The CGM exhibit complex internal growth zoning; the following primary zones were distinguished from centre to rim of columbite-tantalite crystals (Fig. $1 \mathrm{a}-\mathrm{d}$ ). Central zone (A) is slightly heterogeneous, showing locally fine oscillatory zoning. Adjacent heterogeneous intermediate zone $(B)$ is developed particularly on (001) plane of the (A), whereas on prismatic planes of (A) only narrow and discontinuous zone (B) is present (Fig. 1a-b). The zone (B) consists of heterogeneous columbite-tantalite with irregular to patchy zoning in intergrowths with common anhedral tapiolite- $(\mathrm{Fe})$ grains, up to $200 \mu \mathrm{m}$ in diameter (Fig. 1a-c). The next intermediate zone (C) is moderately heterogeneous, locally with oscillatory zoning (Fig. 1c) and rare inclusions of jarosite. Very thin outer zone (D) is seen chiefly on (001) plane and shows fine but contrasting oscillatory zoning relative to the other units (Fig. 1b, d). Subsolidus patchy portions, up to $300 \mu \mathrm{m}$ in size, are evident particularly within the (C) and (D) zones, respectively (Fig. 1b, d). Late veinlets are observed especially in the (C) and (D) zones (Fig. 1b, 2a-b). Similar subsolidus but finer patches and veinlets (Fig. 2a, e, g) also occur close to jarosite pseudomorphs after pyrite.

Hexahedral or irregular inclusions occur in centralouter parts of the CGM crystals. They reveal a $\mathrm{K}-\mathrm{Na}-\mathrm{Pb}$ sulphate composition of the jarosite-group minerals and apparently represent pseudomorphs after primary pyrite. Two morphological types of pyrite pseudomorphs were distinguished in all primary zones of the columbite-tantalite except for the outer one (D). Large subhedral to euhedral grains of pyrite, up to $250 \mu \mathrm{m}$ across, occur on the contact of central zone $\mathrm{A}$ or intermediate $\mathrm{C}$ zone of columbite-tantalite (Fig. 1a, e-f, 2a). These large grains of pyrite were completely altered to jarosite-group minerals (Fig. 1d). Small elongated grains of pyrite, $\sim 20 \mu \mathrm{m}$ long and also completely altered to jarosite-group minerals, are commonly oriented along the $c$ axis of CGM. They are present chiefly within the intermediate zone $\mathrm{C}$ (Figs 1b, 2b), less commonly also in the central zone (A) and intermediate zone (B) (Fig. 1b-c). No changes in primary composition of adjacent columbite-tantalite were recorded directly at the contacts of former pyrite in BSE images (Fig. 1e). However, element mapping revealed several irregular patches of Mn-enriched and Ta-depleted columbite-tantalite $(\leq 100 \mu \mathrm{m})$ close to them (Fig. 2a) as well as a complex network of slightly $\mathrm{Mn}, \mathrm{Nb}$-enriched veinlets of CGM. They occur directly next to the pyrite grains and continue mainly into the intermediate zone $\mathrm{C}$ and less commonly also into the central zone (A) (Fig. 2a-b). Moreover, rare small inclusions of zircon and a $\mathrm{Fe}, \mathrm{Al}$-phosphate mineral (strengite?) are present within the intermediate B zone (Fig. 1b-c).

\subsection{Mineral composition}

The central zone (A) of the columbite-tantalite grains is characterized by slightly heterogeneous columbite-( $\mathrm{Fe})$ to tantalite- $(\mathrm{Fe})$ with $\mathrm{Mn} /(\mathrm{Mn}+\mathrm{Fe})=0.12-0.22$ and $\mathrm{Ta} /(\mathrm{Ta}$ $+\mathrm{Nb})=0.44-0.59$ (Fig. 3a; Tab. 2). Heterogeneous tantalite-( $\mathrm{Fe})$ from the intermediate zone B exhibits $\mathrm{Mn} /(\mathrm{Mn}+$ $\mathrm{Fe}$ ) of $0.15-0.39$ and $\mathrm{Ta} /(\mathrm{Ta}+\mathrm{Nb}$ ) of $0.50-0.62$ (Fig. 3a); associated ferrotapiolite is also relatively heterogeneous $[\mathrm{Mn} /(\mathrm{Mn}+\mathrm{Fe})=0.03-0.05, \mathrm{Ta} /(\mathrm{Ta}+\mathrm{Nb})=0.79-0.92]$ (Fig. 3a). Columbite-(Fe) to tantalite-(Fe) from the intermediate zone $\mathrm{C}$ is rather homogeneous $[\mathrm{Mn} /(\mathrm{Mn}+$ $\mathrm{Ta})=0.16-0.21, \mathrm{Ta} /(\mathrm{Ta}+\mathrm{Nb})=0.49-0.54]$ (Fig. 3a). Columbite-(Fe) from the outer zone (D) is homogeneous in $\mathrm{Mn} /(\mathrm{Mn}+\mathrm{Fe})(0.19-0.22)$ but it shows wide variations in $\mathrm{Ta} /(\mathrm{Ta}+\mathrm{Nb})$ ratios $(0.25$ to 0.41$)$ (Fig. 3a). Columbite$(\mathrm{Fe})$ to tantalite- $(\mathrm{Fe})$ patches adjacent to small grains of the former pyrite are enriched in $\mathrm{Mn}[\mathrm{Mn} /(\mathrm{Mn}+\mathrm{Fe})=$ $0.39-0.42]$, whereas the $\mathrm{Ta} /(\mathrm{Ta}+\mathrm{Nb})$ ratios of $0.48-0.51$ are similar to those of host tantalite-(Fe) of the intermediate zone $\mathrm{C}$ (Fig. 3b). Columbite-(Fe) of the late veinlets is slightly $\mathrm{Nb}$-enriched $[\mathrm{Ta} /(\mathrm{Ta}+\mathrm{Nb})=0.39-0.46]$, whereas its $\mathrm{Mn} /(\mathrm{Mn}+\mathrm{Fe})$ of $0.16-0.26$ is comparable to the host primary columbite-tantalite (Fig. 3a). Other detected cations in CGM include $\mathrm{Ti}\left(\leq 3.3 \mathrm{wt} . \% \mathrm{TiO}_{2} ; 0.17 \mathrm{apfu}\right)$, $\mathrm{W}\left(\leq 2.8\right.$ wt. $\left.\% \mathrm{WO}_{3} ; 0.045 \mathrm{apfu}\right)$ and $\mathrm{Zr}(\leq 0.8$, mostly $\sim 0.3$ wt. $\left.\% \mathrm{ZrO}_{2} ; 0.011 \mathrm{apfu}\right)$. Only trace amounts of $\mathrm{Sn}$ $\left(\leq 0.3\right.$ wt. $\left.\% \mathrm{SnO}_{2}\right)$ and $\mathrm{Pb}(\leq 0.2$ wt. $\% \mathrm{PbO})$ were found. Tapiolite-(Fe) compositions show typically very low and nearly constant $\mathrm{Mn} /(\mathrm{Mn}+\mathrm{Fe})$ but very high and slightly variable $\mathrm{Ta} /(\mathrm{Ta}+\mathrm{Nb})$ atomic ratios: 0.02 to 0.04 and 0.79 to 0.91 , respectively (Tab. 3 ). In tapiolite-(Fe), $\mathrm{W}$ is mostly below the detection limit of EMPA, whereas the concentrations of $\mathrm{ZrO}_{2}$ and $\mathrm{SnO}_{2}$ both attain up to $0.3 \mathrm{wt}$. $\%(\leq 0.01 \mathrm{Zr}$ or Sn apfu), and are in general comparable to columbite-tantalite (Tab. 3).

Fig. 2 The X-ray elemental maps of columbite-group minerals from the Šjby pegmatite (details of Fig. 1a-b). Inclusion in Fig. 2a, c, e and $f$ is decomposed pyrite. 

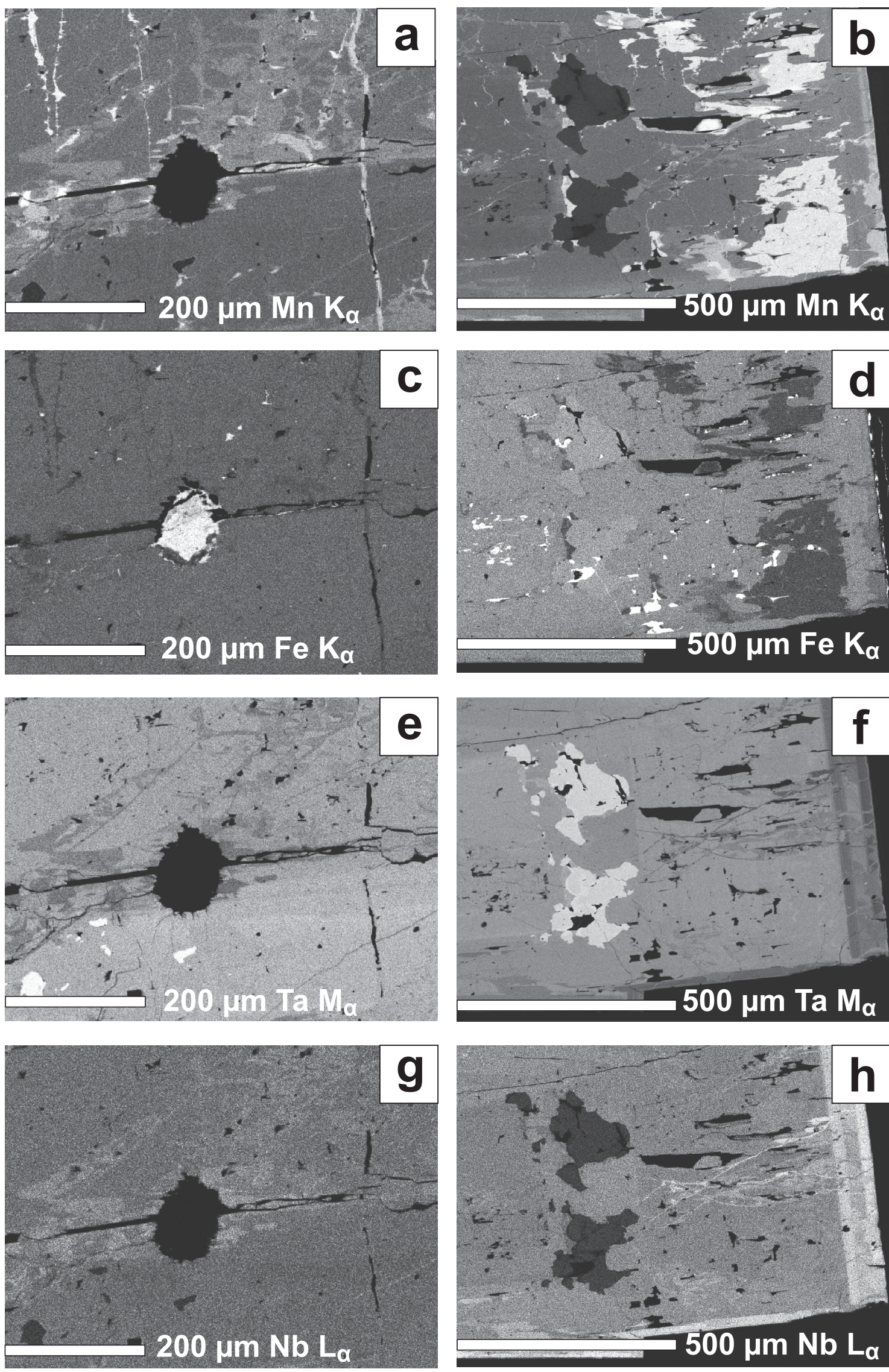
Tab. 2. Representative chemical compositions (in wt. \%) and mineral formulae (in apfu) of CGM from the Šejby pegmatite

\begin{tabular}{|c|c|c|c|c|c|c|c|c|c|c|c|c|}
\hline Zone & (A) & (A) & (B) & (B) & (C) & (C) & (D) & (D) & (S) & (S) & (L) & (L) \\
\hline Analysis \# & 1 & 9 & 14 & 24 & 35 & 37 & 41 & 43 & 51 & 67 & 76 & 83 \\
\hline $\mathrm{WO}_{3}$ & 0.32 & 1.47 & 1.10 & 0.90 & 0.83 & 0.95 & 1.03 & 1.76 & 1.02 & 1.58 & 1.00 & 1.23 \\
\hline $\mathrm{Nb}_{2} \mathrm{O}_{5}$ & 25.65 & 33.71 & 28.09 & 26.78 & 27.05 & 27.42 & 37.05 & 46.70 & 28.58 & 29.40 & 34.20 & 38.70 \\
\hline $\mathrm{Ta}_{2} \mathrm{O}_{5}$ & 55.57 & 43.98 & 50.94 & 52.26 & 51.46 & 50.05 & 41.14 & 31.00 & 51.40 & 49.40 & 44.72 & 40.60 \\
\hline $\mathrm{TiO}_{2}$ & 0.95 & 2.18 & 1.90 & 1.70 & 2.04 & 2.40 & 1.10 & 1.46 & 1.33 & 1.44 & 1.23 & 1.06 \\
\hline $\mathrm{ZrO}_{2}$ & 0.34 & 0.32 & 0.42 & 0.21 & 0.45 & 0.43 & 0.12 & 0.00 & 0.31 & 0.02 & 0.17 & 0.00 \\
\hline $\mathrm{SnO}_{2}$ & 0.04 & 0.22 & 0.16 & 0.21 & 0.17 & 0.20 & 0.09 & 0.08 & 0.06 & 0.09 & 0.10 & 0.05 \\
\hline $\mathrm{UO}_{2}$ & 0.09 & 0.10 & 0.18 & 0.08 & 0.05 & 0.09 & 0.04 & 0.03 & 0.08 & 0.05 & 0.02 & 0.08 \\
\hline $\mathrm{Y}_{2} \mathrm{O}_{3}$ & 0.06 & 0.03 & 0.01 & 0.04 & 0.05 & 0.09 & 0.07 & 0.00 & 0.13 & 0.02 & 0.11 & 0.01 \\
\hline $\mathrm{Sb}_{2} \mathrm{O}_{3}$ & 0.00 & 0.01 & 0.09 & 0.00 & 0.00 & 0.00 & 0.00 & 0.00 & 0.13 & 0.09 & 0.00 & 0.00 \\
\hline $\mathrm{Fe}_{2} \mathrm{O}_{3}$ & 0.42 & 0.96 & 0.49 & 0.44 & 0.99 & 1.32 & 1.15 & 0.00 & 0.58 & 1.14 & 1.14 & 0.30 \\
\hline $\mathrm{FeO}$ & 13.84 & 12.58 & 13.39 & 12.82 & 12.68 & 11.77 & 13.01 & 14.40 & 9.03 & 8.62 & 13.11 & 13.93 \\
\hline $\mathrm{MnO}$ & 1.97 & 3.56 & 2.50 & 2.89 & 2.71 & 3.33 & 3.37 & 3.53 & 6.82 & 7.05 & 3.04 & 3.26 \\
\hline $\mathrm{PbO}$ & 0.12 & 0.16 & 0.12 & 0.13 & 0.08 & 0.12 & 0.14 & 0.00 & 0.13 & 0.01 & 0.15 & 0.00 \\
\hline Total & 99.35 & 99.27 & 99.40 & 98.44 & 98.55 & 98.15 & 98.31 & 96.96 & 99.60 & 98.90 & 98.99 & 99.22 \\
\hline $\mathrm{W}^{6+}$ & 0.006 & 0.026 & 0.020 & 0.017 & 0.015 & 0.018 & 0.018 & 0.035 & 0.019 & 0.029 & 0.018 & 0.022 \\
\hline $\mathrm{Nb}^{5+}$ & 0.844 & 1.043 & 0.900 & 0.873 & 0.873 & 0.882 & 1.147 & 1.368 & 0.916 & 0.938 & 1.067 & 1.182 \\
\hline $\mathrm{Ta}^{5+}$ & 1.095 & 0.818 & 0.981 & 1.025 & 0.999 & 0.969 & 0.765 & 0.546 & 0.990 & 0.948 & 0.839 & 0.746 \\
\hline $\mathrm{Ti}^{4+}$ & 0.052 & 0.112 & 0.101 & 0.092 & 0.109 & 0.128 & 0.057 & 0.073 & 0.071 & 0.078 & 0.064 & 0.059 \\
\hline $\mathrm{Zr}^{4+}$ & 0.012 & 0.011 & 0.014 & 0.007 & 0.016 & 0.015 & 0.004 & 0.000 & 0.011 & 0.001 & 0.006 & 0.000 \\
\hline $\mathrm{Sn}^{4+}$ & 0.001 & 0.006 & 0.005 & 0.006 & 0.005 & 0.006 & 0.003 & 0.002 & 0.002 & 0.003 & 0.003 & 0.001 \\
\hline Sum $B$ & 2.010 & 2.016 & 2.021 & 2.020 & 2.017 & 2.017 & 1.994 & 2.024 & 2.009 & 1.996 & 1.997 & 2.009 \\
\hline $\mathrm{U}^{4+}$ & 0.001 & 0.002 & 0.003 & 0.001 & 0.001 & 0.001 & 0.001 & 0.000 & 0.001 & 0.001 & 0.000 & 0.001 \\
\hline $\mathrm{Y}^{3+}$ & 0.002 & 0.001 & 0.000 & 0.002 & 0.002 & 0.003 & 0.002 & 0.000 & 0.005 & 0.001 & 0.004 & 0.000 \\
\hline $\mathrm{Sb}^{3+}$ & 0.000 & 0.000 & 0.003 & 0.000 & 0.000 & 0.000 & 0.000 & 0.000 & 0.004 & 0.006 & 0.000 & 0.000 \\
\hline $\mathrm{Fe}^{3+}$ & 0.024 & 0.049 & 0.026 & 0.024 & 0.056 & 0.071 & 0.060 & 0.000 & 0.033 & 0.060 & 0.060 & 0.015 \\
\hline $\mathrm{Fe}^{2+}$ & 0.839 & 0.720 & 0.793 & 0.773 & 0.757 & 0.701 & 0.745 & 0.780 & 0.538 & 0.600 & 0.758 & 0.787 \\
\hline $\mathrm{Mn}^{2+}$ & 0.122 & 0.206 & 0.152 & 0.177 & 0.165 & 0.200 & 0.195 & 0.194 & 0.407 & 0.419 & 0.178 & 0.187 \\
\hline $\mathrm{Pb}^{2+}$ & 0.002 & 0.003 & 0.002 & 0.002 & 0.002 & 0.002 & 0.003 & 0.000 & 0.003 & 0.000 & 0.003 & 0.000 \\
\hline $\operatorname{Sum} A$ & 0.990 & 0.981 & 0.979 & 0.979 & 0.983 & 0.979 & 1.006 & 0.974 & 0.991 & 1.086 & 1.003 & 0.990 \\
\hline Sum of cations & 3.000 & 3.000 & 3.000 & 3.000 & 3.000 & 3.000 & 3.000 & 2.998 & 3.000 & 3.000 & 3.000 & 2.999 \\
\hline $\mathrm{Mn} /(\mathrm{Mn}+\mathrm{Fe})$ & 0.127 & 0.222 & 0.161 & 0.186 & 0.179 & 0.222 & 0.207 & 0.199 & 0.431 & 0.411 & 0.190 & 0.192 \\
\hline $\mathrm{Ta} /(\mathrm{Ta}+\mathrm{Nb})$ & 0.565 & 0.440 & 0.522 & 0.540 & 0.534 & 0.523 & 0.400 & 0.285 & 0.519 & 0.503 & 0.440 & 0.387 \\
\hline
\end{tabular}

Mineral formulae based on 3 cations and valence calculation

(A) central zone, (B) intermediate zone B, (C) intermediate zone C, (D) outer zone, (S) subsolidus patches, (L) late veins

\section{Discussion and conclusions}

\subsection{Compositional evolution of columbite- tantalite + ferrotapiolite}

The examined grains of columbite-tantalite + ferrotapiolite show quite complex primary compositional trends (Fig. 3), disregarding simple internal structure of the pegmatite, and simple mineral assemblages almost free of $\mathrm{Fe}, \mathrm{Mn}, \mathrm{Mg}$-bearing primary minerals. The central zone (A) of complexly zoned CGM crystals yielded rather homogeneous columbite-( $\mathrm{Fe}$ ) to tantalite-( $\mathrm{Fe})$ compositions that straddle the boundary of the tapiolite-tantalite immiscibility field (Černý et al. 1992). The CGM of the intermediate zone B ("tapiolite zone" of Fig. 3) generally reveal higher $\mathrm{Ta} /(\mathrm{Ta}+\mathrm{Nb})=0.50-0.62$ and $\mathrm{Mn} /$ $(\mathrm{Mn}+\mathrm{Fe})=0.15-0.39$ than the previous (A) zone (Fig. 3). The composition of the tapiolite-tantalite pair is very similar to that from the Moravany nad Váhom pegmatite, Slovakia (Novák et al. 2000). The next intermediate zone $\mathrm{C}$ has tantalite-( $\mathrm{Fe})$ of an almost identical composition and only columbite-(Fe) from the outer zone (D) exhibits evident decrease in $\mathrm{Ta} /(\mathrm{Ta}+\mathrm{Nb})$ whereas $\mathrm{Mn} /(\mathrm{Mn}+\mathrm{Fe})$ is comparable to the other zones. Chiefly in the intermediate zones $\mathrm{B}$ and $\mathrm{C}$ are present several remarkable $\mathrm{Mn}$-enriched patches (or veinlets) of columbite-( $\mathrm{Fe})$ to tantalite-(Fe) with $\mathrm{Mn} /(\mathrm{Mn}+\mathrm{Fe})$ of $0.39-0.42$, i.e. distinctly higher than in any other zones (Fig. 2a-b). They may represent products of early subsolidus reactions, evidently preceding late veinlets present in all zones and showing only minor Mn enrichment (Fig. 3).

Such a complicated zoning of $\mathrm{Nb}-\mathrm{Ta}$ oxide minerals in relatively simple pegmatite seems to reflect not only changes in $\mathrm{P}-\mathrm{T}$ conditions (mainly decrease in temperature) but also crystal-structural constraints of the relevant minerals. The existence of the tapiolite-tantalite immisci- 
bility field (Černý et al. 1992) resulted in the formation of the tantalite-(Fe) + ferrotapiolite pair instead of a single CGM during increasing $\mathrm{Ta} /(\mathrm{Ta}+\mathrm{Nb})$ in the parental pegmatite melt. This demonstrates a significant role of crystal-structural constraints on the chemical composition of the oxide minerals in the system $\mathrm{Fe}-\mathrm{Mn}-\mathrm{Nb}-\mathrm{Ta}$ $\pm \mathrm{Ti}, \mathrm{W}, \mathrm{Sn}$.

The melt that produced the Šejby granitic pegmatite was relatively rich in Ta at initial magmatic stage, as indicated by the crystallization of the Ta-rich central (A) and the intermediate (B) zones. However, columbite$(\mathrm{Fe})$ to tantalite- $(\mathrm{Fe})$ from intermediate zone $(\mathrm{C})$ shows a relatively slight decrease in Ta and this trend is intensified by the crystallization of columbite$(\mathrm{Fe})$ from the outer zone (D). Moreover, the late patchy parts and veinlets show lower $\mathrm{Ta} /(\mathrm{Ta}$ $+\mathrm{Nb}$ ) than the most evolved magmatic CGM from the zone (B). These late domains were probably connected with latemagmatic or early subsolidus stage of the Šejby pegmatite evolution.

The observed decrease in $\mathrm{Ta} /(\mathrm{Ta}+\mathrm{Nb})$ of the CGM is opposite to common magmatic trend, whereby this value increases due to extended fractionation and precipitation of more incompatible and soluble Ta-rich compositions (Černý et al. 1985, 1986; Černý 1989; Linnen and Keppler 1997; Linnen 1998). However, comparable evolution has been observed in some granitic pegmatites, commonly associated with latemagmatic or early subsolidus

Fig. 3 Composition and evolutionary trends of $\mathrm{Nb}-\mathrm{Ta}$ oxide minerals from the Šejby pegmatite. a - The columbite quadrilateral diagram showing compositional variations of various CGM primary zones (A to D) and secondary domains ( $\mathrm{S}$ and $\mathrm{L}$ ) and associated tapiolite-(Fe); b - Representative compositional profiles reflecting $\mathrm{Mn} /(\mathrm{Mn}+\mathrm{Fe})$ and $\mathrm{Ta} /(\mathrm{Ta}+\mathrm{Nb})$ ratios in the studied CGM. Positions of the point analyses in the profiles are illustrated in Fig. 1e (profiles 1 and 2) and $1 \mathrm{f}$ (profile 3). albitization and with partial dissolution-reprecipitation of early $\mathrm{Nb}-\mathrm{Ta}$ oxide minerals (e.g. Uher et al. 1994; Wang et al. 1997; Tindle and Breaks 2000; Novák et al. 2003; Rao et al. 2009; Chudík et al. 2011; Neiva et al. 2015). This $\mathrm{Nb}$-enrichment and reversal of $\mathrm{Nb} / \mathrm{Ta}$ values of CGM can be attributed to the late-magmatic addition of relatively $\mathrm{Nb}$-rich melt or complex fluid-melt interactions (Černý et al. 1986; London 2008). Alternatively, the reverse compositional trend can be explained by crystallization of CGM from a late-magmatic Na-rich
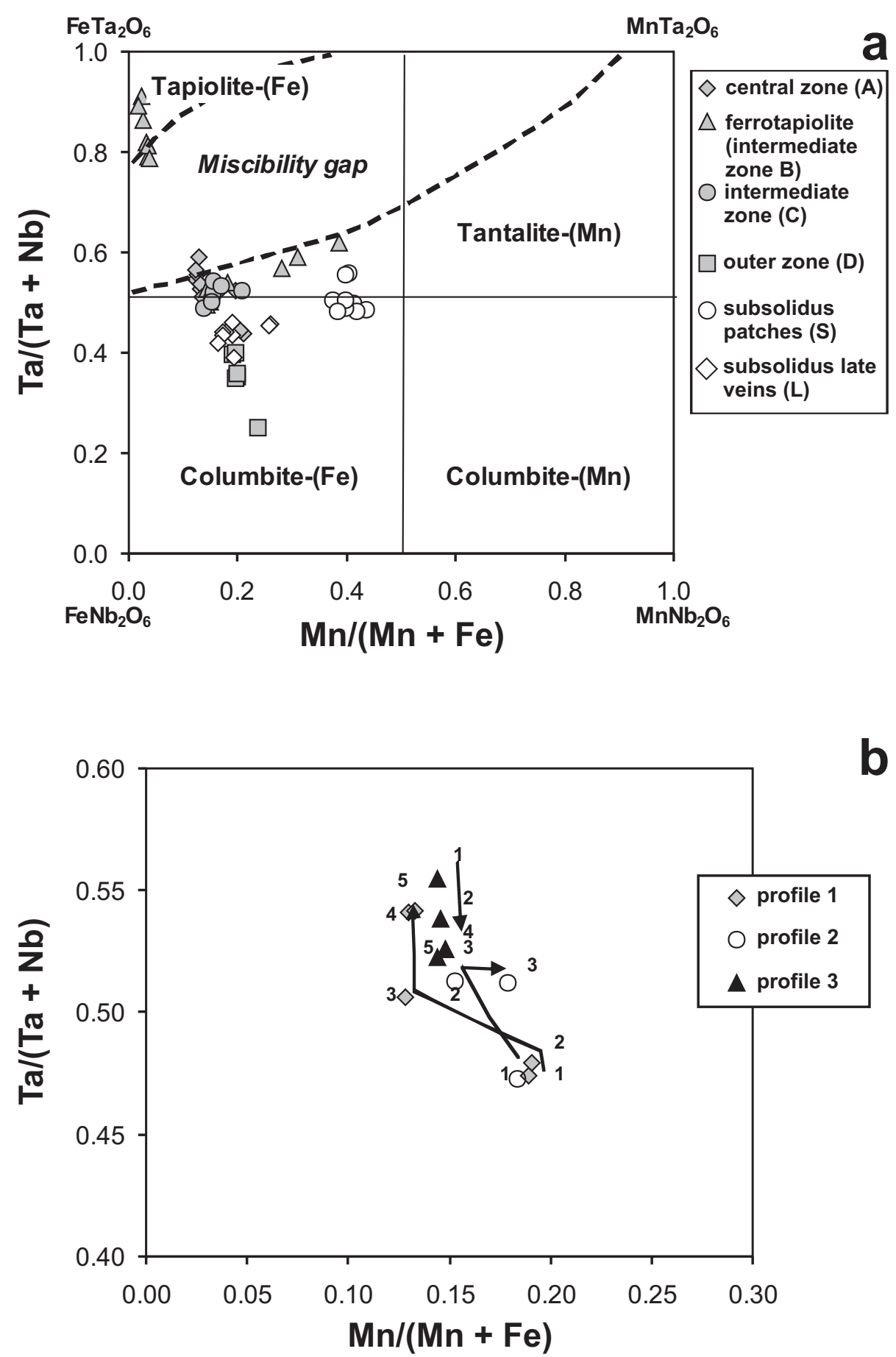
Tab. 3. Representative chemical compositions (in wt. \%) and mineral formulae (in apfu) of tapiolite-(Fe) from the Šejby pegmatite

\begin{tabular}{|c|c|c|c|c|c|}
\hline Analysis \# & 1 & 2 & 3 & 4 & 5 \\
\hline $\mathrm{WO}_{3}$ & 0.14 & 0.21 & 0.00 & 0.02 & 0.02 \\
\hline $\mathrm{Nb}_{2} \mathrm{O}_{5}$ & 11.40 & 10.10 & 7.20 & 5.71 & 4.65 \\
\hline $\mathrm{Ta}_{2} \mathrm{O}_{5}$ & 70.74 & 73.10 & 74.87 & 77.59 & 78.15 \\
\hline $\mathrm{TiO}_{2}$ & 1.86 & 1.26 & 1.71 & 1.66 & 1.69 \\
\hline $\mathrm{ZrO}_{2}$ & 0.24 & 0.00 & 0.09 & 0.09 & 0.08 \\
\hline $\mathrm{SnO}_{2}$ & 0.28 & 0.22 & 0.31 & 0.25 & 0.18 \\
\hline $\mathrm{UO}_{2}$ & 0.04 & 0.02 & 0.00 & 0.00 & 0.00 \\
\hline $\mathrm{Sc}_{2} \mathrm{O}_{3}$ & 0.04 & 0.05 & 0.00 & 0.04 & 0.02 \\
\hline $\mathrm{Y}_{2} \mathrm{O}_{3}$ & 0.04 & 0.00 & 0.07 & 0.00 & 0.09 \\
\hline $\mathrm{As}_{2} \mathrm{O}_{3}$ & 0.01 & 0.00 & 0.02 & 0.03 & 0.00 \\
\hline $\mathrm{Sb}_{2} \mathrm{O}_{3}$ & 0.09 & 0.00 & 0.00 & 0.00 & 0.06 \\
\hline $\mathrm{Bi}_{2} \mathrm{O}_{3}$ & 0.00 & 0.00 & 0.04 & 0.00 & 0.00 \\
\hline $\mathrm{Fe}_{2} \mathrm{O}_{3}$ & 0.68 & 0.06 & 0.38 & 0.46 & 0.72 \\
\hline $\mathrm{FeO}$ & 13.66 & 14.15 & 13.54 & 13.65 & 13.27 \\
\hline $\mathrm{MnO}$ & 0.54 & 0.42 & 0.37 & 0.25 & 0.31 \\
\hline $\mathrm{MgO}$ & 0.02 & 0.03 & 0.00 & 0.01 & 0.00 \\
\hline $\mathrm{CaO}$ & 0.01 & 0.00 & 0.00 & 0.00 & 0.00 \\
\hline $\mathrm{PbO}$ & 0.03 & 0.00 & 0.00 & 0.00 & 0.03 \\
\hline Total & 99.83 & 99.62 & 98.60 & 99.76 & 99.26 \\
\hline $\mathrm{W}^{6+}$ & 0.003 & 0.004 & 0.000 & 0.000 & 0.000 \\
\hline $\mathrm{Nb}^{5+}$ & 0.400 & 0.362 & 0.263 & 0.208 & 0.172 \\
\hline $\mathrm{Ta}^{5+}$ & 1.495 & 1.575 & 1.648 & 1.705 & 1.735 \\
\hline $\mathrm{Ti}^{4+}$ & 0.109 & 0.075 & 0.104 & 0.101 & 0.104 \\
\hline $\mathrm{Zr}^{4+}$ & 0.009 & 0.000 & 0.003 & 0.004 & 0.003 \\
\hline $\mathrm{Sn}^{4+}$ & 0.009 & 0.007 & 0.010 & 0.008 & 0.006 \\
\hline $\mathrm{U}^{4+}$ & 0.001 & 0.000 & 0.000 & 0.000 & 0.000 \\
\hline $\mathrm{Sc}^{3+}$ & 0.003 & 0.003 & 0.000 & 0.003 & 0.001 \\
\hline $\mathrm{Y}^{3+}$ & 0.002 & 0.000 & 0.003 & 0.000 & 0.004 \\
\hline $\mathrm{As}^{3+}$ & 0.001 & 0.000 & 0.001 & 0.002 & 0.000 \\
\hline $\mathrm{Sb}^{3+}$ & 0.003 & 0.000 & 0.000 & 0.000 & 0.002 \\
\hline $\mathrm{Bi}^{3+}$ & 0.000 & 0.000 & 0.001 & 0.000 & 0.000 \\
\hline $\mathrm{Fe}^{3+}$ & 0.040 & 0.003 & 0.023 & 0.028 & 0.044 \\
\hline $\mathrm{Fe}^{2+}$ & 0.888 & 0.937 & 0.917 & 0.923 & 0.906 \\
\hline $\mathrm{Mn}^{2+}$ & 0.035 & 0.028 & 0.025 & 0.017 & 0.021 \\
\hline $\mathrm{Mg}^{2+}$ & 0.002 & 0.004 & 0.000 & 0.001 & 0.000 \\
\hline $\mathrm{Ca}^{2+}$ & 0.001 & 0.000 & 0.000 & 0.000 & 0.000 \\
\hline $\mathrm{Pb}^{2+}$ & 0.001 & 0.000 & 0.000 & 0.000 & 0.001 \\
\hline Sum of cations & 3.000 & 3.000 & 3.000 & 3.000 & 3.000 \\
\hline $\mathrm{Mn} /(\mathrm{Mn}+\mathrm{Fe})$ & 0.037 & 0.029 & 0.026 & 0.018 & 0.022 \\
\hline $\mathrm{Ta} /(\mathrm{Ta}+\mathrm{Nb})$ & 0.789 & 0.813 & 0.862 & 0.891 & 0.910 \\
\hline
\end{tabular}

Mineral formulae based on 3 cations and valence calculation

Contents of $\mathrm{P}$, Th and $\mathrm{Zn}$ were below detection limits

melt, significantly depleted in Ta with the respect to $\mathrm{Nb}$ after crystallization of a relatively large amount of Tarich CGM, tapiolite-(Fe) and ferrowodginite of the first magmatic generation (Chudík et al. 2011).

\subsection{Role of associated minerals}

Only a few authors have reported chemical influences of various $\mathrm{Fe}$ - and $\mathrm{Mn}$-bearing minerals on the composition of the associated CGM. Mulja et al. (1996) explained a progressive increase in $\mathrm{Ta} /(\mathrm{Ta}+\mathrm{Nb})$ at a constant $\mathrm{Mn} /$
$(\mathrm{Mn}+\mathrm{Fe})$ by the contemporaneous crystallization of CGM with garnet at the Lacorne pegmatites, Quebec (Canada). In the Tanco pegmatite deposit, Manitoba, Canada, the Fe-Mn composition of the melt was controlled by the coprecipitation of $\mathrm{Fe}$-rich tourmaline (schorl to elbaite) with CGM, which led to an increase of $\mathrm{Mn} /(\mathrm{Mn}+\mathrm{Fe})$ ratio in associated columbite-tantalite (Van Lichtervelde et al. 2006). Crystallization of abundant Mn-rich fluorapatite could have depleted the melt in Mn and prevent substantial increase of the $\mathrm{Mn} /(\mathrm{Mn}+\mathrm{Fe})$ ratio in associated columbite-tantalite in highly fractionated, P, F-rich granite at Podlesí, Czech Republic (Breiter et al. 2007).

Although the above-mentioned Fe, Mn-bearing minerals may play a significant role in $\mathrm{Fe}-\mathrm{Mn}$ fractionation, the assemblage CGM + pyrite does not appear to have any influence on $\mathrm{Fe}-\mathrm{Mn}$ fractionation during primary crystallization of the Šejby pegmatite. The $\mathrm{Mn} / \mathrm{Fe}$ ratio of the $\mathrm{Nb}-\mathrm{Ta}$ minerals did not change significantly due to the general scarcity of other Mn-bearing minerals such as garnet, tourmaline or phosphates. Only Mn-rich fluorapatite with up to $6.6 \mathrm{wt}$. \% $\mathrm{MnO}(\leq 0.46 \mathrm{apfu} \mathrm{Mn}$; Pavlíček et al. 2009) could theoretically have influenced the $\mathrm{Mn} / \mathrm{Fe}$ ratio of $\mathrm{Nb}-\mathrm{Ta}$ phases. However, direct (or close) paragenetic relationships between apatite and $\mathrm{Nb}-$ Ta oxide minerals have not been observed and apatite is rather rare. Such a conclusion is supported by negligible compositional changes during magmatic CGM growth (Figs 2-3); even their primary oscillatory zoning was not disrupted (Fig. 1). Moreover, results of the chemical analyses in profiles close to pyrite grains show that there is no extensive enrichment in $\mathrm{Mn}$, which would indicate preferential partitioning of $\mathrm{Fe}$ into pyrite over CGM (Fig. 2a, c). Consequently, crystallization of pyrite did not cause any noticeable Mn-enrichment disregarding expected strong Fe-partitioning into pyrite over CGM.

Late enrichment in $\mathrm{Nb}$ is evident in late veinlets in primary columbite-tantalite from both zones (Fig. 1b, $2 a-b)$. Textural features show that the formation of veinlets and their fillings by the latest generation of CGM was the terminating event in the evolution of the $\mathrm{Nb}-\mathrm{Ta}$ oxide minerals in the Šejby pegmatite. Very low pH of fluids is required for the origin of jarosite-group minerals (e.g. Welch et al. 2008). Thin veinlets and fillings located close to the jarosite pseudomorphs (Fig. 2c) may be related to the pyrite replacement by jarosite and indicate higher mobility of Ta relative $\mathrm{Nb}$ at such acidic conditions. However, the role of $\mathrm{pH}$ in low-T fluids for CGM compositions is worthy of future study (Wood 2005).

\subsection{Comparison to other granitic pegmatites of the Moldanubian Zone}

Mineral assemblages of $\mathrm{Nb}-\mathrm{Ta}-\mathrm{Sn}-\mathrm{Ti}$ oxide minerals from two major leucogranite-pegmatite occurrences (Ho- 
molka, Šejby) and adjacent placers in the Moldanubian Zone of the southern Bohemian Massif are rather variable (Novák et al. 1994; Frýda and Breiter 1995; Uher 1998; Pavlíček et al. 2009).

A more primitive, $\mathrm{Nb}$, Ta-poor and Ti-rich mineral assemblage including cassiterite, niobian and tantalian rutile, ilmenite, pseudobrookite and pseudorutile was described in the Homolka leucogranites and marginal pegmatites (Novák et al. 1994; Uher 1998). Ixiolite is present only as inclusions in niobian rutile whereas individual grains of columbite-( $\mathrm{Fe})$ to tantalite-( $\mathrm{Fe})$ are rare and more evolved CGM members (columbite-(Mn) and tantalite-(Mn)) and tapiolite-(Fe) are absent.

Conversely, chemical composition of CGM and tapiolite$(\mathrm{Fe})$ from the examined Šejby pegmatite documented in previous papers (Novák et al. 1994; Frýda and Breiter 1995; Pavlíček et al. 2009; Welser and Zikeš 2013) and especially in this study (Fig. 3a) shows distinct Nb, Ta-enrichment and higher fractionation degree of the beryl-columbite granitic pegmatites in comparison to the leucogranites and their marginal pegmatite facies. The only similar beryl-columbite pegmatite related to the Eisgarn granite with primary magmatic hurlbutite $\left[\mathrm{CaBe}_{2}\left(\mathrm{PO}_{4}\right)_{2}\right]$ is known from Kostelní Vydř́ near Telč (Novák 1994; Cempírek et al. 1999). Here, columbite-( $\mathrm{Fe})$ shows $\mathrm{Nb} / \mathrm{Ta}$ fractionation $[\mathrm{Ta} /(\mathrm{Ta}+\mathrm{Nb})$ $=0.27-0.37]$ but almost constant $\mathrm{Mn} /(\mathrm{Mn}+\mathrm{Fe})$ ratio $(0.07-0.10)$ resembling the studied Šejby pegmatite.

By comparison, compositional trends in columbitetantalite and associated $\mathrm{Nb}$, Ta-oxide minerals from tourmaline-rich pegmatites of the Moldanubian Zone varying from beryl (beryl-columbite subtype) to complex (lepidolite, elbaite, petalite subtype) types, are entirely different (see Novák and Černý 1998, 2001). Less evolved beryl-columbite pegmatites with niobian (tantalian) rutile and columbite exhibit significant $\mathrm{Fe} / \mathrm{Mn}$ fractionation, whereas $\mathrm{Ta} /(\mathrm{Ta}+\mathrm{Nb})$ are low and rather constant (e.g., Černý et al. 2000, 2007). Complex pegmatites typically contain columbite-(Mn) with very high $\mathrm{Mn} /(\mathrm{Mn}+\mathrm{Fe})$ but commonly low $\mathrm{Ta} /(\mathrm{Ta}+\mathrm{Nb}$ ) (Novák and Černý 1998, 2001). Significant role of associated abundant tourmaline (schorl-foitite-dravite) controlling the activity of Fe is evident because it was preferentially incorporated into tourmaline and associated CGM are typically Mn-rich (e.g., London et al. 2001; Van Lichtervelde et al. 2006).

Acknowledgements. The paper has benefited greatly from the critical reviews by M. A. Wise and A. Pieczka and Associated Editor J. Sejkora. We also thank to P. Welser and $\mathrm{J}$. Zikeš for field assistance. This study was supported by the Masaryk University project MUNI/A/1653/2016 (to MN and PG), Slovak Research and Development Agency under the contract APVV-14-0278 (to PU), and by the Ministry of Education of the Slovak Republic, project VEGA-1/0499/16 (to PU).

\section{References}

Aseri AA, Linnen RL, Che XD, Thibault Y, Holtz F (2015) Effects of fluorine on the solubilities of $\mathrm{Nb}$, Ta, $\mathrm{Zr}$ and Hf minerals in highly fluxed water-saturated haplogranitic melts. Ore Geol Rev 64: 736-746

Badanina EV, Sitnikova MA, Gordienko VV, Melcher F, GÄBLER HE, LodzIAK J, Syritso LF (2015) Mineral chemistry of columbite-tantalite from spodumene pegmatites of Kolmozero, Kola Peninsula (Russia). Ore Geol Rev 64: 720-735

Bartels A, Holtz F, Linnen RL (2010) Solubility of manganotantalite and manganocolumbite in pegmatitic melts. Amer Miner 95: 537-544

Bartels A, Vetere F, Holtz F, Behrens H, Linnen RL (2011) Viscosity of flux-rich pegmatitic melts. Contrib Mineral Petrol 162: 51-60

BARTh M, McDonough W, Rudnick R (2000) Tracking the budget of $\mathrm{Nb}$ and $\mathrm{Ta}$ in the continental crust. Chem Geol 165: 197-213

Beurlen H, Da Silva MrR, Thomas R, Soares DR, OliVIER P (2008) Nb-Ta-(Ti-Sn) oxide mineral chemistry as tracer of rare element granitic pegmatite fractionation in the Borborema Province, Northeastern Brazil. Miner Depos 43: 207-228

Breiter K (1998) Phosphorus- and fluorine-rich granite system at Podlesí (Excursion stop. No. 3). In: BreITER K (ed) Genetic Significance of Phosphorus in Fractionated Granites - Excursion Guide. Czech Geological Survey, Prague, pp 59-75

Breiter K, Scharbert S (1998) Latest intrusions of the Eisgarn Pluton (South Bohemia, northern Austria). Jb Geol BA 141: 25-37

Breiter K, ŠKoda R, Uher P (2007) Nb-Ta-Ti-W-Snoxide minerals as indicators of peraluminous $\mathrm{P}$ - and Frich granitic system evolution: Podlesí, Czech Republic. Mineral Petrol 91: 225-248

Cempírek J, Novák M, VÁvra V (1999) Hurlbutite from beryl-columbite pegmatite in Kostelní Vydří near Telč, western Moravia. Acta Mus Morav Sci Geol 84: 45-48 (in Czech)

ČERNÝ P (1989) Characteristics of pegmatite deposits of tantalum. In: Möller P, Černý P, SAupé F (eds) Lanthanides, Tantalum and Niobium. Springer-Verlag, Heidelberg, pp 195-239

ČERnÝ P (1992) Geochemical and petrogenetic features of mineralization in rare-element granitic pegmatites in the light of current research. Appl Geochem 7: 393-416

ČERnÝ P, ERCIT TS (1985) Some recent advances in the mineralogy and geochemistry of $\mathrm{Nb}$ and $\mathrm{Ta}$ in rare element granitic pegmatites. Bull Minéral 108: 499-532

ČERnÝ P, ERCIT TS (1989) Mineralogy of niobium and tantalum: crystal chemical relationships, paragenetic aspects and their economic implications. In: MöLleR P, ČERNÝ 
P, SAUPÉ F (eds) Lanthanides, Tantalum and Niobium. Mineralogy, Geochemistry, Character of Primary Ore Deposits, Prospecting and Applications. Proceedings of a workshop in Berlin, November 1986. Springer-Verlag, Berlin, pp 27-79

ČERNÝ P, ERCIT TS (2005) The classification of the granitic pegmatites revisited. Canad Mineral 43: 2005-2026

Černý P, Meintzer RE, ANDERson AJ (1985) Extreme fractionation in rare-element granitic pegmatites: selected examples of data and mechanisms. Canad Mineral 23: 381-421

Černý P, Goad BE, Hawthorne FC, Chapman R (1986) Fractionation trends of the $\mathrm{Nb}$ - and Ta-bearing oxide minerals in the Greer Lake pegmatitic granite and its pegmatite aureole, southeastern Manitoba. Amer Miner 71: 501-517

ČERNÝ P, ERCIT TS, WISE MA (1992) The tantalite-tapiolite gap; natural assemblages versus experimental data. Canad Mineral 30: 587-596

Černý P, Novák M, Chapman R (2000) Subsolidus behavior of niobian rutile from Věžná, Czech Republic: a model for exsolution in phases with $\mathrm{Fe}^{2+}>>\mathrm{Fe}^{3+}$. $\mathrm{J}$ Czech Geol Soc 45: 21-35

Černý P, Novák M, Chapman R, Ferreira KJ (2007) Subsolidus behavior of niobian rutile from Písek region, Czech Republic: a model for exsolution in $\mathrm{W}-$ and $\mathrm{Fe}^{2+}$ > $\mathrm{Fe}^{3+}$-rich phases. J Geosci 52: 143-159

Chevychelov VY (2014) Experimental study of the magmatic stage genesis of tantalum deposits associated with the lithium-fluorine granites. Acta Geol Sin 88: 423-425

Chevychelov VY, Borodulin GP, Zaraisky GP (2010) Solubility of columbite, $(\mathrm{Mn}, \mathrm{Fe})(\mathrm{Nb}, \mathrm{Ta})_{2} \mathrm{O}_{6}$, in granitoid and alkaline melts at $650-850{ }^{\circ} \mathrm{C}$ and $30-400 \mathrm{MPa}$ : an experimental investigation. Geochem Int 48: 456-464

Chudík P, Uher P, Gadas P, ŠKoda R, Pršek J (2011) Niobium-tantalum oxide minerals in the Jezuitské Lesy granitic pegmatite, Bratislava Massif, Slovakia: Ta to $\mathrm{Nb}$ and Fe to Mn evolutionary trends in a narrow Be, Cs-rich and Li, B-poor dike. Mineral Petrol 102: 15-27

FrÝDA J, BREITER K (1995) Alkali feldspars as a main phosphorus reservoirs in rare-metal granites: three examples from the Bohemian Massif (Czech Republic). Terra Nova 7: 315-320

GALLISKI MA, ČERNÝ P (2006) Geochemistry and structural state of columbite group minerals in granitic pegmatites of the Pampean Ranges, Argentina. Canad Mineral 44: 645-666

Gerdes A (2001) Magma homogenization during anatexis, ascent and/or emplacement? Constraints from the Variscan Weinsberg granites. Terra Nova 13: 305-312

Gerdes A, Friedl G, Parrish, Finger RRF (2003) High resolution geochronology of Variscan granite emplacement - the South Bohemian Batholith. J Czech Geol Soc 48: 53-54
HeŘMánek R, Čekal F, MatěJKa D, KlečKa M (1998) Geochemistry, petrology and mineralogy of the two mica granites from the Novohradské hory Mts. Area. Zpr Geol Výzk v r 1997: 86-88 (in Czech)

KLöTZLI US (1999) Resolving complex geological histories by zircon dating: a discussion of case studies from the Bohemian Massif and the Eastern Alps. Mitt Österr Geol Ges 90: 31-41

LAHTI SI (1987) Zoning in columbite-tantalite crystals from the granitic pegmatites of the Eräjärvi area, southern Finland. Geochim Cosmochim Acta 51: 509-517

LAHTI SI (2000) Compositional variation in columbitegroup minerals from different types of granitic pegmatites of the Eräjärvi district, South Finland. J Czech Geol Soc 45: $107-118$

LiNNEN RL (1998) The solubility of Nb-Ta-Zr-Hf-W in granitic melts with $\mathrm{Li}$ and $\mathrm{Li}+\mathrm{F}$ : constraints for mineralization of rare metal granites and pegmatites. Econ Geol 93: 1013-1025

LINNEN RL, CUNEY M(2005) Granite-related rare-element deposits and experimental constraints on $\mathrm{Ta}-\mathrm{Nb}-\mathrm{W}-\mathrm{Sn}-\mathrm{Zr}-$ Hf mineralization. In: LinNEN RL, SAMSON IM (eds) Rare Element Geochemistry and Mineral Deposits. Geological Association of Canada Short Course Notes 17: pp 45-68

LinNen RL, KePPLeR H (1997) Columbite solubility in granitic melts: consequences for the enrichment and fractionation of $\mathrm{Nb}$ and $\mathrm{Ta}$ in the Earth's crust. Contrib Mineral Petrol 128: 213-227

London D (2008) Pegmatites. Canadian Mineralogist, Special Publications 10: 1-347

LONDON D, Evensen JM, Fritz E, ICENHOWER JP (2001) Enrichment and accommodation of manganese in granite-pegmatite systems. $11^{\text {th }}$ Annual Goldschmidt Conference, May 20-24, 2001, Hot Springs, Virginia, Abstract n. 3369

MatĚJKa D, KlečKa M (1994) Kurze Mitteilung über hoch differenzierte Muskovit-Granite (Typ Šejby) aus dem Novohradské hory-Gebirge (Südböhmen). Jb Geol B-A 137: 295-296

Melcher F, Graupner T, Gäbler HE, Sitnikova M, Kunst FH, Oberthür T, Gerdes A, Dewaele S (2015) Tantalum-(niobium-tin) mineralisation in African pegmatites and rare metal granites: constraints from $\mathrm{Ta}-\mathrm{Nb}$ oxide mineralogy, geochemistry and $\mathrm{U}-\mathrm{Pb}$ geochronology. Ore Geol Rev 64: 667-719

Mulja T, Williams-Jones AE, Martin RF, Wood SA (1996) Compositional variation and structural state of columbite-tantalite in rare-element granitic pegmatites of the Preissac-Lacorne Batholith, Quebec, Canada. Amer Miner 81: 146-157

Nerva AMR, Gomes CL, SiLva PB (2015) Two generations of zoned crystals of columbite-group minerals from granitic aplite-pegmatite in the Gouveia area, central Portugal. Eur J Mineral 27: 771-782 
NovÁK M (1994) Ferrocolumbite from beryl-columbite pegmatite from Kostelní Vydří near Telč, western Moravia. Acta Mus Morav Sci Nat 79: 3-8 (in Czech)

NovÁK M, ČERnÝ P (1998) Niobium-tantalum oxide minerals from complex granitic pegmatites in the Moldanubicum, Czech Republic: primary versus secondary compositional trends. Canad Mineral 36: 659-672

NovÁK M, ČERnÝ P (2001) Distinctive compositional trends in columbite-tantalite from two segments of the lepidolite pegmatite at Rožná, western Moravia, Czech Republic. J Czech Geol Soc 46: 1-8

Novák M, KlečKa M, Šrein V (1994) Compositional evolution of $\mathrm{Nb}$, Ta-oxide minerals from alkali-feldspar muscovite granites Homolka and Šejby southern Bohemia, and its comparison with other rare-element granites. Mitt Österr Mineral Ges 139: 353-354

Novák M, Uher P, Černý P, Siman P (2000) Compositional variations in ferrotapiolite + tantalite pairs from the beryl-columbite pegmatite at Moravany nad Váhom, Slovakia. Mineral Petrol 69: 295-306

NovÁK M, ČERNÝ P, UHER P (2003) Extreme variation and apparent reversal of $\mathrm{Nb}-\mathrm{Ta}$ fractionation in columbitegroup minerals from Scheibengraben beryl-columbite granitic pegmatite, Maršíkov, Czech Republic. Eur J Mineral 15: 565-574

PAVlíčeK V, Breiter K, ŠKodA R (2009) Pegmatite of beryl-columbite type from Šejby, Novohradské Highland, Czech Republic. Zpr Geol Výzk v r 2008: 185-189 (in Czech)

Pouchou JL, PichoIr F (1985) "PAP” ( $\varphi \rho Z)$ procedure for improved quantitative microanalysis. In: ARMSTRONG JT (ed) Microbeam Analysis. San Francisco Press, San Francisco, pp 104-106

Raimbault L (1998) Composition of complex lepidolitetype granitic pegmatites and of constituent columbitetantalite, Chédeville, Massif Central, France. Canad Mineral 36: 563-583

Rao C, Wang RC, Hu H, Zhang WL (2009) Complex internal textures in oxide minerals from the Nanping No. 31 dyke of granitic pegmatite, Fujian Province, southeastern China. Canad Mineral 47: 1195-1212

SPILDE MN, SHEARER CK (1992) A comparison of tantalum-niobium oxide assemblages in two mineralogically distinct rare-element granitic pegmatites, Black Hills, South Dakota. Canad Mineral 30: 719-737

Stepanov A, Mavrogenes JA, Mefrre S, Davidson P (2014) The key role of mica during igneous concentration of tantalum. Contrib Mineral Petrol 167: 1009

Tindle AG, Breaks FW (2000) Columbite-tantalite mineral chemistry from rare-element granitic pegmatites: Separation Lake, N.W. Ontario, Canada. Mineral Petrol 70: 165-198

Uher P (1998) Composition of Nb, Ta, Sn-bearing oxide minerals from the Homolka phosphorus-rich granite, Czech Republic. Acta Univ Carol Geol 42: 169-172

Uher P, ČERnÝ P, NovÁK M, Siman P (1994) Niobiumtantalum minerals from granitic pegmatites in the Malé Karpaty, Považský Inovec and Žiar mountains, Western Carpathians, Slovakia. Miner Slov 26: 157-164

Van Lichtervelde M, Linnen RL, Salvi S, Beziat D (2006) The role of metagabbro rafts on tantalum mineralization in Tanco granitic pegmatite, Manitoba. Canad Mineral 44: 625-644

Van Lichtervelde M, Salvi S, Beziat D, Linnen R (2007) Textural features and chemical evolution in tantalum oxides: magmatic versus hydrothermal origins for Ta mineralization in Tanco Lower Pegmatite, Manitoba, Canada. Econ Geol 102: 257-276

WANG RCH, Fontan F, Xu SJ, Chen XM, Monchoux P (1997) The association of columbite, tantalite and tapiolite in Sushou granite, China. Canad Mineral 35: 699-706

Welch SA, Kirste D, Christy AG, Beavis FR Beavis S (2008) Jarosite dissolution II - reaction kinetics, stoichiometry and acid flux. Chem Geol 254: 73-86

Welser P, Zikeš J (2013) Pegmatites from Šejby in the Novohradské Highland. Minerál 21: 387-409 (in Czech)

Wood SA (2005) The aqueous geochemistry of zirconium, hafnium, niobium and tantalum. In: LINNEN RL, SAMSON IM (eds) Rare-element Geochemistry and Mineral Deposits. Geological Association of Canada Short Course Notes 17: pp 217-250

ŽÁK J, Verner K, Finger F, FARyad SW, Chlupáčová M, VESELOVSKÝ F (2011) The generation of voluminous Stype granites in the Moldanubian unit, Bohemian Massif, by rapid isothermal exhumation of the metapelitic middle crust. Lithos 121: 25-40 